\title{
THE FORMALITIES OF EVIL
}

DOUGLAS WALTON

University of Winnipeg

We set out here a formalization of the argument from evil, i.e., a first-order deduction of a first-order inconsistency from certain premisses alleged to be essential to theism or necessary truths. Formalization is not sufficient for solution or dissolution of the problem, but is helpful in isolating and stating contentious assumptions, and thereby in providing a foundation for possible solutions.

Some have affirmed, others denied, that there is a logical contradiction derivable from assumptions plausibly attributed to classidal theism. Mackie [4]* asserts, but does not explicitly prove, that there does exist such a logical contradiction. Mavrodes [5], page 98, denies the charge, pointing out that nobody has ever succeeded in making the contradiction plain.

According to Mackie [4], the problem may be located within these three statements:

(1) A good thing always eliminates evil as far as it can.

(2) There are no limits to what an omnipotent thing can do.

(3) A good omnipotent thing eliminates evil completely.

The first premiss is thought to be connected with the general assumption that good is opposed to evil. (3) is supposed to follow deductively from (1) and (2). The problem is that it is alleged to follow from (3) that is there is a good, omnipotent thing, there is no evil. In opposition to this, theism seems to hold that there is a good omnipotent thing and there is also evil.

* References corresponding to those numbers which appear in brackets can be found at the end of the article. 
We re-word 'Mackie's set of statements, without significantly altering their import for the problem, as follows:

(4) A good being always prevents evil if he can.

(5) An omnipotent being can prevent anything.

(6) A good, omnipotent being prevents all evil.

Now we introduce undefined predicate expressions:

G (1) : (1) is good P(1) (2) : (1) prevents (2)

$O$ (1) : (1) is omnipotent C (1) (2): (1) can prevent (2)

B (1): (1) is bad

The first-order structure of (4), (5), and (6) is exhibited, respectively, in the triad below:

(7) $(\forall x)(G x \supset(\forall y)(B y \supset(C x y \supset P x y)))$

(8) $(\forall x)(O x \supset(\forall y) C x y)$

(9) $(\forall x)(G x \supset(0 x \supset(\forall y)(B y \supset P x y)))$

We next postulate as a premiss an alleged assumption of theism, namely that a being exists that is both good and omnipotent:

(10) $(\exists x)(G x \& O x)$

Now consider the individual $a$ of whom (10) is true. By (9), it is true of $a$ that

$$
\text { (11) ( } \forall \text { y) (B y } \supset \text { P ay) }
$$

We have now arrived at the conclusion that there is an individual who prevents every bad thing. If we wish to stay within first-order logic exclusively, it is required that we make the following assumption to reach the desired conclusion:

(12) ( $\exists \cdot x)(\forall y)(B y \supset$ P xy) $\supset \sim(\exists z) B z$

Then since the individual $a$ referred to in (11) satisfies the 
hypothesis of (12), it follows that

(13) $\sim(\exists \mathrm{z}) \mathrm{Bz}$

But of course (13) is truth-functionally inconsistent with a well-known assumption of classical theism, namely,

(14) ( $\exists \mathrm{z}) \mathrm{B} \mathrm{z}$

Here then we attain the desired first-order inconsistency. A "Q.E.D." may not be inappropriate at this point.

It may be premature for the atheologian to rejoice, however, for the premiss on which (12) would seem most likely based cannot be expressed in a first-order logic. A more general basis of (12) plausibly resides in the necessary truth that if $a$ prevents $b$ then $b$ does not occur. This statement could be expressed in a system like that suggested by Hintikka [3] wherein we can quantify over non-existent individuals. We might state the required assumption as follows:

(15) $(\forall x)(\forall y)(P x y \supset \sim(\exists z) x=y)$

But according to the standard interpretation of quantification theory (see Quine [7]), (15) cannot express the truth "If $a$ prevents $b$ then $b$ does not obtain," since the consequent of (15) is the negation of a theorem of standard quantification theory. A second way to express this necessary truth in firstorder logic would be to introduce a predicate 'H(1)' read as '(1) occurs.' This procedure is equally non-standard, however, for it requires some way of alleviating the problem that according to the usual interpretation of quantification theory, ' $\mathrm{Ha}$ ' would seem to be a theorem, unless ' $\mathrm{H}$ (1)' is interpreted in what seems to be a non-standard way.

Yet if (12) is acceptable as a necessary truth, and it is hard to see how it might be refuted, then the contradiction is exclusively first-order derivable from $(7) ;(8)$. (10), (12), and (14). The total of five assumptions may now be classified as follows: (8), (10), and (14) are thought to be assumptions essential to theism, and (7) and (12) are 
thought to be necessary truths.

One final word on the general project of formalization. It was required above in the use of the two dyadic predicate expressions that we quantify over "events." Another method would be to treat "prevents" and "can prevent" as operators as in Walton [8]. This proposal would, however, take us outside first-order logic. The merits of both ways of proceeding are discussed generally in Cresswell [1]. Suffice it to say here that the value of the foregoing proposal for the formalization of the problem of evil is directly dependent on the feasibility of quantifying over individuals as "events."

I refrain from general remarks on the relevance of the formalization to the various solutions that have been offered to the problem of evil, except for mentioning three points of direct interest. First, it is clear that since the deduction takes place through first-order steps only, a consistent theism must reject at least one of the premisses $(7),(8),(10),(12)$ or (14). Geach [2] would appear to wish to reject (10) on the ground that God, though almighty, is not literally omnipotent, e.g., God cannot break a promise. Plantinga [6] would appear to reject (8) in his claim that God, although omnipotent, could not have created just any possible world he pleased.

\section{REFERENCES}

[1] M. J. Cresswell, "Adverbs and Events," Synthese, forthcoming.

[2] Peter Geach, "Omnipotence," Philosophy, 48, 1973, pp. 7-20.

[3] Jaakko Hintikka, Models for Modalities, Dordrecht, Reidel, 1969.

[4] J. L. Mackie, "Evil and Omnipotence," Mind, LXIV, 1955, pp. $200-212$.

[5] George Mavrodes, Belief in God, New York, Random House, 1970.

[6] Alvin Plantinga, The Nature of Necessity, Oxford, Oxford University Press, 1974.

[7] W. V. O. Quine, "Quantification and the Empty Domain," Selected Logic Papers, New York, Random House, 1966, pp. 220-223.

[8] Douglas Walton, "The Omnipotence Paradox," Canadian Journal of Philo. sophy, Vol. IV, No. 4 June, 1975. 
RESUMEN

Presentamos una formalización del argumento del mal, esto es, una deducción de primer orden de una inconsistencia de primer orden a partir de ciertas premisas que se mantiene que son esenciales al teísmo o son verdades necesarias. Hay quienes han afirmado que una contradicción lógica es derivable de supuestos que se atribuyen plausiblemente al teísmo clásico.

Conforme a Mackie [4], el problema puede localizarse dentro de los siguientes tres enunciados:

(1) Una cosa buena siempre elimina el mal hasta donde le es posible.

(2) Lo que una cosa omnipotente puede hacer no tiene límites.

(3) Una cosa buena y. omnipotente elimina el mal por completo.

(1) se piensa que está relacionado con el supuesto general de que el bien se opone al mal. (3) se supone que se sigue deductivamente de (1) y (2). El problema es que se mantiene que de (3) se sigue que si hay una cosa buena y omnipotente, no hay mal. En contra de esto el teismo parece mantener que hay una cosa buena y omnipotente y que también hay mal.

Reformulando el conjunto de enunciados de Mackie de la siguiente forma:

(4) Una cosa buena siempre impide el mal si puede

(5) Una cosa omnipotente puede impedir cualquier cosa

(6) Una cosa buena y omnipotente impide todo el mal

e introduciendo las siguientes expresiones predicativas:

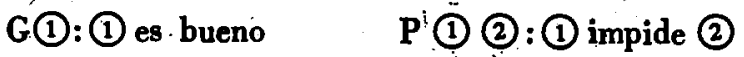

0(1): (1) es omnipotente C. (1) (2):(1) puede impedir (2)

B(1):(1) es malo

podemós mostrar la estructura de primer orden de (4), (5) y (6) de la siguiente manera:

(7) $(\forall x)(G x \supset(\forall y)(B y \supset(C x y \supset P x y)))$ 
(8) $(\forall x)(0 x \supset(\forall y) C x y)$

(9) $(\forall x)(G x \supset(0 x \supset(\forall y)(B y \supset P x y)))$

Introducimos ahora como premisa un supuesto del teísmo:

(10) $(\exists x)(G x \& O x)$

y de (9) y (10), asumiendo que (10) verdadero de un $a$, obtenemos:

$$
\text { (11) ( } \forall \text { y) (B y } \supset \text { P ay) }
$$

Si deseamos mantenernos dentro de la lógica de primer orden exclusivamente, se requiere que formulemos el siguiente supuesto para alcanzar la conclusión deseada:

$$
(\exists x)(\forall y)(B y \supset P x y) \supset \sim(\exists z) B z
$$

Ahora de (11) y (12) se sigue:

(13) $\sim(\exists \mathbf{z}) \mathrm{B} \mathbf{z}$

Pero esto es inconsistente con un bien conocido supuesto del teísmo clásico, a saber:

(14) (

No es el momento, sin embargo, para que el no teólogo se rego. cije, pues la premisa en la que sería más plausible fundar (12) no puede expresarse en una lógica de primer orden. Aun se presentan otros problemas intentando fundar (12) en una premisa en términos de lógica de primer orden.

Sin embargo, si (12) es aceptable como una verdad necesaria, entonces la contradicción es exclusivamente derivable en lógica de primer orden de (7), (8), (10), (12) y (14) y estos supuestos se pueden clasificar de la siguiente manera: (8), (10) y (14) se piensa que son supuestos esenciales del teísmo y (7) y (12) se piensa que son verdades necesarias.

Hay que tener en cuenta, sin embargo, que el valor de la propuesta previa de formalización depende directamente de la factibilidad de cuantificar sobre individuos como "sucesos".

Por último mencionaré los siguientes puntos: un teísmo consistente debe rechazar al menos una de las premisas $(7),(8),(10),(12)$ 
o (14). Geach [2] parece que desea rechazar (10) sobre la base de que Dios, aun cuando todo poderoso, no es literalmente omnipotente; por ejemplo, Dios no puede quebrantar una promesa. Plantinga [6] parece que rechaza (8) al mantener que Dios, aun cuando omnipotente, no podría haber creado cualquier mundo posible que desease.

(Resumen de José A. Robles) 